\title{
Analisa QoS Pada Penerapan Local IPTV Dalam Jaringan IEEE 802.11
}

\author{
Sri Hartanto \\ Teknik Elektro \\ Universitas Krisnadwipayana \\ Jakarta, Indonesia \\ srihartanto@unkris.ac.id
}

\begin{abstract}
IPTV merupakan protokol aplikasi TCP/IP yang menggunakan pengalamatan internet (IP Address) dalam suatu jaringan telekomunikasi untuk pengiriman konten multimedia berbentuk audio video, yaitu berupa layanan siaran televisi digital. Dalam perkembangannya, IPTV tidak hanya digunakan untuk mentransmisikan konten siaran televisi dari perusahaan siaran televisi (TV Broadcasting) yang sudah mapan, tetapi juga dapat digunakan untuk mentransmisikan konten siaran televisi lokal pada cakupan terbatas, seperti suatu lingkungan masyarakat, kantor, kampus atau suatu komunitas tertentu. Sebagaimana umumnya siaran televisi dalam mode transmisi simplex, televisi lokal ini bersumber dari suatu komputer server yang menyediakan konten televisi digital yang dapat diakses oleh sejumlah pengguna melalui suatu jaringan lokal dengan cara men-setting IP Address media player pada unit penerima. Unit penerima tersebut dapat berupa PC Portabel (Notebook), tablet atau smartphone, sedangkan media player yang digunakan untuk Local IPTV ini adalah VLC Media Player. Agar dapat memberikan kenyamanan bagi pengguna Local IPTV, perlu adanya jaminan kualitas layanan (Quality of Service $=$ QoS). QoS dalam Local IPTV ini dapat diukur dan dianalisa dari kemampuan jaringan lokal dalam mentransmisikan sinyal audio video dengan baik. Oleh karena itu, penelitian ini akan mengukur dan menganalisa QoS Local IPTV dalam jaringan LAN nirkabel atau jaringan IEEE 802.11. Parameter QoS yang diukur dan dianalisa adalah perbandingan jarak terminal client ke Access Point terhadap kecepatan data (bit rate), lama waktu memulai siaran (initial time), latency dan kualitas gambar. Metodologi yang digunakan adalah membangun jaringan IEEE 802.11 dengan satu komputer sebagai Server Televisi dan dua smartphone, dua notebook dan dua tablet sebagai terminal client; membangun Server Televisi dan men-setting VLC Media Player; menguji coba dan mengambil data pengukuran berupa kecepatan data (bit rate), lama waktu memulai siaran (initial time), latency dan kualitas gambar pada televisi lokal berbasis IP; serta menganalisanya.
\end{abstract}

Kata kunci-Local IPTV; QoS; jaringan IEEE 802.11; VLC Media Player.

\section{PENDAHULUAN}

Penggunaan teknologi audio video streaming dalam suatu jaringan paket data dapat memberikan suatu layanan televisi lokal dengan daerah cakupan terbatas. Dibandingkan dengan televisi konvensional, televisi lokal ini dapat menghadirkan informasi secara khusus yang dapat dipilih oleh pengguna melalui terminal client. Konten televisi lokal dikhususkan pada informasi berupa lingkungan, hobi dan minat komunitas, serta media pembelajaran. Informasi lingkungan biasanya disesuaikan dengan kekhasan dari daerah dimana jaringan paket data dibangun, seperti kampus, kantor, lingkungan masyarakat perkotaan, atau lingkungan masyarakat pedesaan. Informasi hobi dan minat komunitas umumnya berkaitan dengan karakteristik pengguna yang memiliki akses ke jaringan paket data yang dibangun. Sedangkan media pembelajaran lebih diarahkan untuk memberikan pengetahuan dan informasi praktis dalam bentuk audio video.

Sebagaimana umumnya siaran televisi dalam mode transmisi simplex, televisi lokal ini bersumber dari suatu komputer server yang menyediakan konten televisi digital yang dapat diakses oleh sejumlah pengguna melalui suatu jaringan lokal dengan cara men-setting IP Address media player pada unit penerima. Unit penerima tersebut dapat berupa PC Portabel (Notebook), tablet atau smartphone, sedangkan media player yang digunakan untuk Local IPTV ini adalah VLC Media Player. Agar dapat memberikan kenyamanan bagi pengguna Local IPTV, perlu adanya jaminan kualitas layanan (Quality of Service $=$ QoS). QoS dalam Local IPTV ini dapat diukur dan dianalisa dari kemampuan jaringan lokal dalam mentransmisikan sinyal audio video dengan baik.

Oleh karena itu, penelitian ini akan mengukur dan menganalisa QoS Local IPTV dalam jaringan LAN nirkabel atau jaringan IEEE 802.11. Parameter QoS yang diukur dan dianalisa adalah perbandingan jarak terminal client ke Access Point terhadap kecepatan data (bit rate), lama waktu memulai siaran (initial time), latency dan kualitas gambar. Penelitian ini menggunakan VLC Media Player dalam jaringan LAN Nirkabel (IEEE 802.11). Jarak terminal client yang diamati dibatasi hingga jarak 30 meter dari Access Point, dengan interval pengukuran setiap 10 meter. 


\section{TEORI DASAR}

Teknologi streaming adalah teknologi untuk memutar audio video yang disimpan dalam komputer server yang dapat diakses oleh terminal client melalui suatu jaringan telekomunikasi secara real time sehingga terbentuk suatu buffer di terminal client dan file audio video ini mulai diunduh ke dalam buffer yang dibentuk pada terminal client. Dalam waktu tertentu, buffer telah terisi penuh dan secara otomatis, informasi berupa file audio video dijalankan oleh sistem. Sistem membaca informasi dari buffer sambil tetap melakukan proses mengunduh file sehingga proses streaming tetap berlangsung pada terminal client. Waktu tunda (delay) sesaat sebelum file audio video dijalankan berkisar 10 sampai dengan 30 detik. Konfigurasi teknologi streaming diperlihatkan dalam Gambar 1 berikut:.

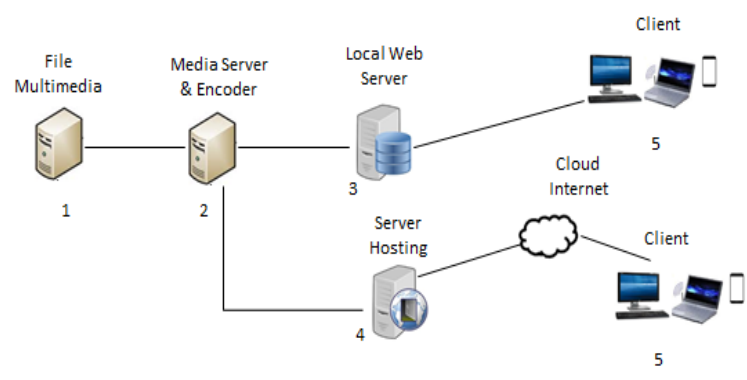

Gambar 1. Konfigurasi Teknologi Streaming

Proses streaming terdiri atas:

1. Layanan Server Televisi

Server Televisi berfungsi mengatur komunikasi dan mengontrol pengiriman data streaming melalui jaringan paket data.

2. Distribusi File Audio Video

Proses ini melibatkan banyak interkoneksi jaringan buffer pada Server Televisi.

3. Pemutaran siaran televisi lokal

Proses ini menggunakan media player yang diembed pada web browser dan berfungsi untuk menerima data streaming dan melakukan dekompresi kembali ke format audio video semula, dimana data streaming dijalankan pada terminal client.

Pendistribusian file-file audio video yang bersifat on-demand maupun live streaming dilakukan oleh Server Televisi menggunakan protokol pendistribusian yang disesuaikan dengan codec dari video dan audio yang diproduksi. Protokol yang mendukung berjalannya audio video streaming yaitu:

1. Network Protocol dimana routing bersandarkan pada pengalamatan IP.

2. Transport Protocol yang menyediakan konektivitas secara end-to-end dalam jaringan untuk aplikasi streaming yang terbagi menjadi User Datagram Protocol (UDP) dan Transmission Control Protocol (TCP).
3. Session Control Protocol yang mendefinisikan pesan dan prosedur untuk mengatur pengiriman data dari multimedia selama session terbentuk, di antaranya: Real-Time Protocol (RTP), RealTime Streaming Protocol (RTSP), dan Real-Time Control Protocol (RTCP).

Pada media streaming, terminal client mulai mengakses file audio video segera setelah mulai mengunduh. Akibatnya, file dikirim ke pengguna dalam arus konstan (kurang lebih), dan pengguna menontonnya ketika file audio video sampai. Keuntungan yang jelas dengan metode ini adalah tidak ada penundaan. Media streaming memiliki keunggulan tambahan seperti bisa menyiarkan acara live (kadang disebut sebagai webcast atau netcast).

Bandwidth adalah lebar cakupan frekuensi yang digunakan oleh sinyal dalam media transmisi. Dalam hal ini, bandwidth dapat diartikan sebagai perbedaan antara frekuensi tinggi dan frekuensi rendah. Frekuensi sinyal diukur dalam satuan Hertz. Sinyal suara mempunyai bandwidth sekitar $3 \mathrm{kHz}$, analog TV broadcast (TV) mempunyai bandwidth sekitar 6 MHz. Bandwidth dapat juga diartikan sebagai penghitungan konsumsi data yang tersedia pada suatu telekomunikasi. Dihitung dalam satuan bits per seconds (bps). Bandwidth sering disamakan dengan data transfer rate yaitu jumlah data yang dapat dibawa dari sebuah titik ke titik lain dalam jangka waktu tertentu (pada umumnya dalam second (s) atau detik). Secara umum, koneksi dengan bandwidth yang besar/tinggi memungkinkan pengiriman informasi yang besar seperti pengiriman citra (images).

Codec (compression decompression) adalah perangkat untuk memampatkan (compressing) dan mendekompres (decompressing) sejumlah besar data audio video yang digunakan. Suatu codec mengambil data streaming dalam satu bentuk, mengkodekannya menjadi bentuk lain dan memodifikasinya di titik keluaran dalam sesi komunikasi. Codec merupakan proses pengkodean audio yang ditangkap mikrofon atau video yang ditangkap kamera dalam bentuk digital dan dikirim ke terminal client dalam jaringan telekomunikasi. Codec audio dan video menggunakan algoritma perangkat lunak yang berjalan pada prosesor umum atau perangkat keras khusus yang dioptimalkan untuk enkapsulasi data dan dekapsulasi.

VLC Media Player adalah program multimedia player portabel, dan memutar baik video maupun audio dalam berbagai format, seperti MPEG, DivX, Ogg, dan lain-lain. VLC Media Player juga dapat digunakan untuk memutar DVD,VCD, maupun CD. VLC Media Player juga merupakan open source software dan tersedia untuk berbagai sistem operasi. Kelebihan VLC Media Player adalah kelengkapan codec yang dimiliki.

Jaringan LAN Nirkabel (IEEE 802.11) dikenal luas dengan istilah Wi-Fi (Wireless-Fidelity). Wi-Fi Alliance mendefinisikan Wi-Fi sebagai "produk 
jaringan wilayah lokal nirkabel (IEEE 802.11) apapun yang didasarkan pada standar Institute of Electrical and Electronics Engineers (IEEE) 802.11. Suatu perangkat yang memiliki fitur Wi-Fi (seperti komputer pribadi, notebook, smartphone, tablet, atau pemutar audio digital) dapat terhubung ke jaringan nirkabel melalui suatu perangkat titik akses jaringan nirkabel (Access Point). Jangkauan Access Point (AP) sekitar 20 meter di dalam ruangan dan lebih luas lagi di luar ruangan. Terdapat beberapa standar IEEE 802.11 seperti terlihat dalam Tabel 1 berikut:

Tabel 1. Macam-Macam Standar IEEE 802.11

\begin{tabular}{|llll|}
\hline \hline Spesifikasi Kecepatan & $\begin{array}{l}\text { Frekuensi } \\
\text { Band }\end{array}$ & $\begin{array}{l}\text { Cocok } \\
\text { dengan }\end{array}$ \\
\hline \hline $802.11 \mathrm{~b}$ & $11 \mathrm{Mb} / \mathrm{s}$ & $\sim 2.4 \mathrm{GHz}$ & $\mathrm{b}$ \\
\hline \hline $802.11 \mathrm{a}$ & $54 \mathrm{Mb} / \mathrm{s}$ & $\sim 5 \mathrm{GHz}$ & $\mathrm{a}$ \\
\hline \hline $802.11 \mathrm{~g}$ & $54 \mathrm{Mb} / \mathrm{s}$ & $\sim 2.4 \mathrm{GHz}$ & $\mathrm{b}, \mathrm{g}$ \\
\hline $802.11 \mathrm{n}$ & $150 \mathrm{Mb} / \mathrm{s}$ & $\sim 2.4 \mathrm{GHz}$ & $\mathrm{b}, \mathrm{g}, \mathrm{n}$ \\
\hline
\end{tabular}

Agar terhubung dengan LAN Nirkabel, suatu komputer server perlu dilengkapi dengan pengontrol antarmuka jaringan nirkabel. Gabungan komputer server dan pengontrol antarmuka disebut stasiun. Semua stasiun berbagi satu saluran komunikasi frekuensi radio. Transmisi dalam saluran ini diterima oleh semua stasiun yang berada dalam jangkauan. Perangkat keras tidak memberitahu pengguna bahwa transmisi berhasil diterima dan ini disebut mekanisme pengiriman terbaik.

\section{METODOLOGI PENELITIAN}

Metode penelitian yang dilakukan dapat dilihat pada Gambar 2 berikut:

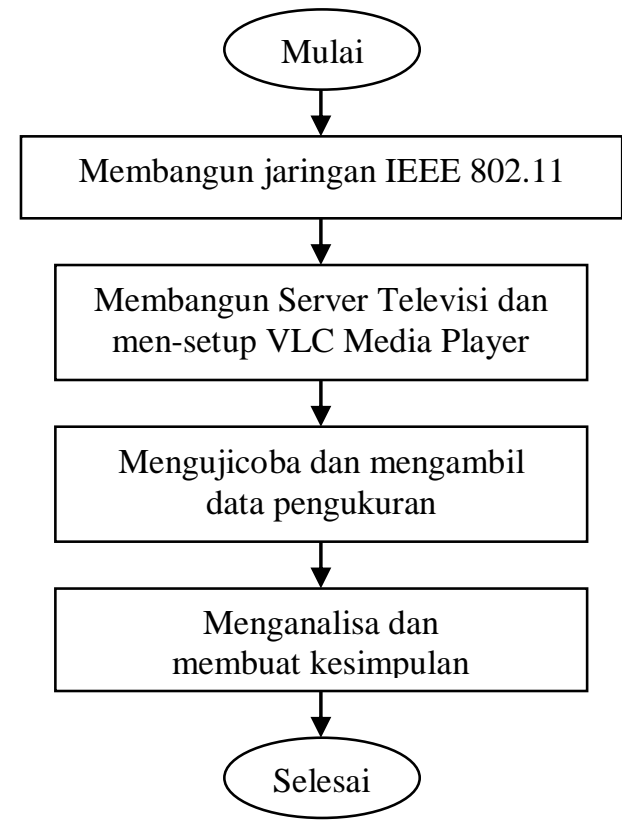

Gambar 2. Metode Penelitian
Metode penelitian yang dilakukan adalah:

1. Membangun jaringan IEEE 802.11 menggunakan satu komputer sebagai Server Televisi dan dua smartphone, dua notebook dan dua tablet sebagai terminal client.

2. Men-setting VLC Media Player pada satu komputer sebagai Server Televisi dan enam terminal client.

3. Mengujicoba dan mengambil data pengukuran berupa kecepatan data (bit rate), lama waktu memulai siaran (initial time), latency dan kualitas gambar dengan jarak terminal client yang diubahubah, dengan interval 10 meter. Pengambilan data pengukuran menggunakan aplikasi SpeedTest yang dibuka di aplikasi browser terminal client.

4. Menganalisa dan membuat kesimpulan.

A. Membangun Jaringan LAN Nirkabel IEEE 802.11

Dalam penelitian ini dibangun jaringan IEEE 802.11 dengan satu komputer sebagai Server Televisi dan dua smartphone, dua notebook dan dua tablet sebagai terminal client, dimana konfigurasi jaringan IEEE 802.11 diperlihatkan dalam Gambar 3 berikut:

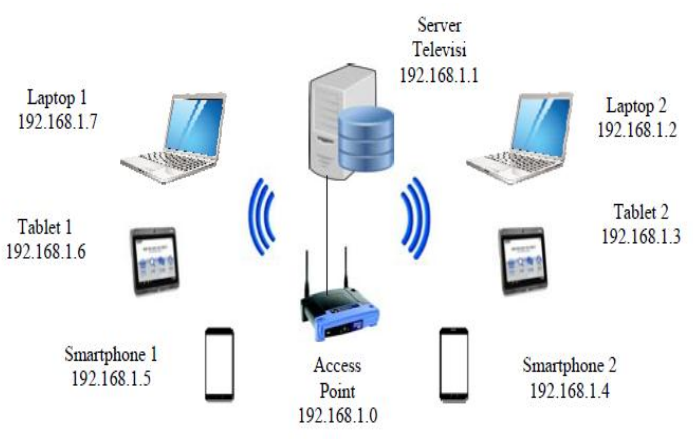

Gambar 3. Konfigurasi Jaringan LAN Nirkabel

Perangkat yang digunakan dalam membangun jaringan IEEE 802.11 adalah:

1. Server Televisi

Dalam penelitian ini, Server Televisi menggunakan PC Desktop dengan mikroprosesor Intel Xeon, dilengkapi kartu jaringan IEEE 802.11, dengan perangkat lunak OS Linux Ubuntu 2011 dan VLC Media Player.

2. Terminal Client

Dalam penelitian ini, Terminal Client terdiri dari dua notebook dengan mikroprosesor Intel 2 Core N3350, dilengkapi kartu jaringan IEEE 802.11, dengan perangkat lunak OS Linux Ubuntu 2011 dan VLC Media Player, serta dua tablet dan dua smartphone dengan mikroprosesor Qualcomm, dilengkapi kartu jaringan IEEE 802.11, dengan perangkat lunak OS Android dan VLC Media Player.

3. Access Point 
Dalam penelitian ini, Access Point yang digunakan adalah yang dapat bekerja pada frekuensi 2,4 GHz.

\section{B. Men-setting VLC Media Player}

Langkah-langkah meng-instal VLC Media Player adalah:

1. Mengunduh perangkat lunak VLC Media Player di link http://www.videolan.org/vlc/, pilih sesuai dengan Operating System (OS) pada komputer yang dijadikan Server Televisi dan pada dua terminal client dalam bentuk notebook, dalam hal ini disesuaikan dengan OS Linux Ubuntu 2011, sedangkan untuk terminal client berbentuk tablet dan smartphone dengan Operating System (OS) Android dapat mengunduhnya di Google Playstore.

2. Meng-instal VLC Media Player dengan mengklik ganda file installer aplikasi tersebut, pada pilihan bahasa penginstalan, pilih English, kemudian klik tombol OK, pada tampilan Welcome To The VLC Media Player Setup Wizard, klik tombol NEXT untuk melanjutkan penginstalan, pada tampilan License Agreement klik tombol NEXT,

3. Memilih komponen-komponen yang akan diinstal bersama VLC Media Player pada bagian Choose Components, klik tombol NEXT, pada pemilihan lokasi instalasi pilih lokasi memori tempat penyimpanan aplikasi VLC Media Player dan klik tombol FINISH untuk mengakhiri penginstalan.

Langkah-langkah men-setting VLC Media

Player pada komputer yang dijadikan sebagai Server Televisi adalah:

1. Pada perangkat lunak VLC Media Player, klik Media, pilih Stream.

2. Pilih File, lalu pilih Add untuk memasukkan file audio video yang dapat disiarkan oleh Server Televisi ke beberapa terminal client, lalu klik Stream.

3. Setelah muncul tampilan Source, klik Next,

4. Setelah itu muncul tampilan Destination, difungsikan untuk memilih jenis video streaming yang digunakan, berikut ini dipilih HTTP sebagai video streaming Broadcast, beri tanda centang pada option display locally.

5. Klik Add, masukkan port 8080 dan pada kotak path, isi dengan nama lokasi streaming, misalnya: televisi, klik Nest,

6. Lalu muncul tampilan Transcoding Option untuk memilih jenis audio video streaming yang akan dimainkan, pilih Video for MPEG4 720p TV/device, lalu klik Next,

7. Pada pilihan Option, beri tanda centang pada option stream all elementary system.

Langkah-langkah untuk men-setup VLC Media Player pada terminal client, baik pada dua notebook,maupun pada dua smartphone dan dua tablet yang mengakses Server Televisi berbasis streaming Broadcast adalah sebagai berikut:
1. Pada perangkat lunak VLC Media Player, pilih Media, lalu pilih Open Network Stream,

2. Masukkan alamat IP Server Televisi dan putar (klik Play) sehingga audio video streaming yang disiarkan Server Televisi dapat dijalankan di terminal client.

\section{ANALISA}

Setelah membangun jaringan IEEE 802.11 dan membangun Server Televisi serta men-setting VLC Media Player sehingga suatu file audio video yang tersimpan di Server Televisi dapat diterima oleh terminal client melalui jaringan IEEE 802.11, selanjutnya dilakukan ujicoba dan mengambil data pengukuran terhadap enam terminal client. Pengambilan data pengukuran menggunakan aplikasi SpeedTest yang dibuka di aplikasi browser terminal client. Hal ini diamati untuk tiga jenis terminal client yang berbeda sehingga dapat diketahui hubungan antara perbandingan jarak terminal dengan Access Point terhadap kecepatan data (bit rate), lama waktu memulai siaran (initial time), latency dan kualitas gambar pada siaran televisi lokal. Jarak terminal client yang diamati dibatasi hingga jarak 30 meter dari Access Point, dengan interval pengukuran setiap 10 meter. Data pengamatan dan pengukuran dapat dilihat pada Tabel 2, 3 dan 4 berikut:

Tabel 2. Data Pengukuran Smartphone

\begin{tabular}{|c|c|c|c|c|c|}
\hline $\begin{array}{l}\text { Smart } \\
\text { phone }\end{array}$ & Jarak & $\begin{array}{l}\text { Bit } \\
\text { Rate }\end{array}$ & $\begin{array}{l}\text { Initial } \\
\text { Time }\end{array}$ & Latency & $\begin{array}{l}\text { Kualitas } \\
\text { Gambar }\end{array}$ \\
\hline Sp 1 & \multirow{2}{*}{$0 \mathrm{~m}$} & $\begin{array}{l}4,1 \\
\text { Mbps }\end{array}$ & $17 \mathrm{~s}$ & $1 \mathrm{~ms}$ & Baik \\
\hline Sp 2 & & $\begin{array}{l}4,15 \\
\text { Mbps }\end{array}$ & $16 \mathrm{~s}$ & $1 \mathrm{~ms}$ & Baik \\
\hline Sp 1 & \multirow{2}{*}{$10 \mathrm{~m}$} & $\begin{array}{l}3,8 \\
\text { Mbps }\end{array}$ & $19 \mathrm{~s}$ & $1 \mathrm{~ms}$ & Baik \\
\hline Sp 2 & & $\begin{array}{l}3,9 \\
\text { Mbps }\end{array}$ & $18 \mathrm{~s}$ & $1 \mathrm{~ms}$ & Baik \\
\hline Sp 1 & \multirow{2}{*}{$20 \mathrm{~m}$} & $\begin{array}{l}3,2 \\
\text { Mbps }\end{array}$ & $22 \mathrm{~s}$ & $0,8 \mathrm{~ms}$ & Cukup \\
\hline Sp 2 & & $\begin{array}{l}3,3 \\
\text { Mbps }\end{array}$ & $21 \mathrm{~s}$ & $0,8 \mathrm{~ms}$ & Cukup \\
\hline Sp 1 & \multirow{2}{*}{$30 \mathrm{~m}$} & $\begin{array}{l}3,0 \\
\text { Mbps }\end{array}$ & $24 \mathrm{~s}$ & $0,7 \mathrm{~ms}$ & Cukup \\
\hline Sp 2 & & $\begin{array}{l}3,1 \\
\text { Mbps }\end{array}$ & $23 \mathrm{~s}$ & $0,7 \mathrm{~ms}$ & Cukup \\
\hline
\end{tabular}

Keterangan: Sp 1: Smartphone 1 (IP: 192.168.1.5)

Sp 2: Smartphone 2 (IP: 192.168.1.4)

Tabel 3. Data Pengukuran Tablet

\begin{tabular}{|l|l|l|l|l|l|}
\hline $\begin{array}{l}\text { Smart } \\
\text { phone }\end{array}$ & Jarak & $\begin{array}{l}\text { Bit } \\
\text { Rate }\end{array}$ & $\begin{array}{l}\text { Initial } \\
\text { Time }\end{array}$ & Latency & $\begin{array}{l}\text { Kualitas } \\
\text { Gambar }\end{array}$ \\
\cline { 1 - 5 } Tb 1 & \multirow{2}{*}{$0 \mathrm{~m}$} & $\begin{array}{l}4,0 \\
\text { Mbps }\end{array}$ & $16 \mathrm{~s}$ & $1 \mathrm{~ms}$ & Baik \\
\cline { 3 - 6 } Tb 2 & $\begin{array}{l}4,1 \\
\text { Mbps }\end{array}$ & $15 \mathrm{~s}$ & $1 \mathrm{~ms}$ & Baik \\
\hline Tb 1 & $10 \mathrm{~m}$ & $\begin{array}{l}3,8 \\
\text { Mbps }\end{array}$ & $18 \mathrm{~s}$ & $1 \mathrm{~ms}$ & Baik \\
\hline
\end{tabular}




\begin{tabular}{|l|l|l|l|l|l|}
\hline Tb 2 & & $\begin{array}{l}3,9 \\
\text { Mbps }\end{array}$ & $17 \mathrm{~s}$ & $1 \mathrm{~ms}$ & Baik \\
\hline \multirow{2nnnyy}{*}{ Tb 1 } & \multirow{2}{*}{$20 \mathrm{~m}$} & $\begin{array}{l}3,5 \\
\text { Mbps }\end{array}$ & $21 \mathrm{~s}$ & $0,8 \mathrm{~ms}$ & Cukup \\
\cline { 1 - 4 } & $\begin{array}{l}3,4 \\
\text { Tb 2 } \\
\text { Mbps }\end{array}$ & $20 \mathrm{~s}$ & $0,8 \mathrm{~ms}$ & Cukup \\
\hline \multirow{2}{*}{ Tb 1 } & $\begin{array}{l}3,3 \\
\text { Mbps }\end{array}$ & $23 \mathrm{~s}$ & $0,7 \mathrm{~ms}$ & Cukup \\
\cline { 1 - 4 } Tb 2 & $\begin{array}{l}3,2 \\
\text { Mbps }\end{array}$ & $22 \mathrm{~s}$ & $0,7 \mathrm{~ms}$ & Cukup \\
\hline
\end{tabular}

Keterangan: Tb 1: Tablet 1 (IP: 192.168.1.6)

Tb 2: Tablet 2 (IP: 192.168.1.3)

Tabel 4. Data Pengukuran Notebook

\begin{tabular}{|c|c|c|c|c|c|}
\hline $\begin{array}{l}\text { Smart } \\
\text { phone }\end{array}$ & Jarak & $\begin{array}{l}\text { Bit } \\
\text { Rate }\end{array}$ & $\begin{array}{l}\text { Initial } \\
\text { Time }\end{array}$ & Latency & $\begin{array}{l}\text { Kualitas } \\
\text { Gambar }\end{array}$ \\
\hline Lp 1 & \multirow{2}{*}{$0 \mathrm{~m}$} & $\begin{array}{l}4,1 \\
\text { Mbps }\end{array}$ & $17 \mathrm{~s}$ & $1 \mathrm{~ms}$ & Baik \\
\hline Lp 2 & & $\begin{array}{l}4,15 \\
\text { Mbps }\end{array}$ & $16 \mathrm{~s}$ & $1 \mathrm{~ms}$ & Baik \\
\hline Lp 1 & \multirow{2}{*}{$10 \mathrm{~m}$} & $\begin{array}{l}3,8 \\
\text { Mbps }\end{array}$ & $19 \mathrm{~s}$ & $1 \mathrm{~ms}$ & Baik \\
\hline Lp 2 & & $\begin{array}{l}3,9 \\
\text { Mbps }\end{array}$ & $18 \mathrm{~s}$ & $1 \mathrm{~ms}$ & Baik \\
\hline Lp 1 & \multirow{2}{*}{$20 \mathrm{~m}$} & $\begin{array}{l}3,5 \\
\text { Mbps }\end{array}$ & $21 \mathrm{~s}$ & $0,8 \mathrm{~ms}$ & Cukup \\
\hline Lp 2 & & $\begin{array}{l}3,4 \\
\text { Mbps }\end{array}$ & $20 \mathrm{~s}$ & $0,8 \mathrm{~ms}$ & Cukup \\
\hline Lp 1 & \multirow{2}{*}{$30 \mathrm{~m}$} & $\begin{array}{l}3,3 \\
\text { Mbps }\end{array}$ & $23 \mathrm{~s}$ & $0,7 \mathrm{~ms}$ & Cukup \\
\hline Lp 2 & & $\begin{array}{l}3,2 \\
\text { Mbps }\end{array}$ & $22 \mathrm{~s}$ & $0,7 \mathrm{~ms}$ & Cukup \\
\hline
\end{tabular}

Keterangan: Lp 1: Notebook 1 (IP: 192.168.1.7)

Lp 2: Notebook 2 (IP: 192.168.1.2)

Dari Tabel 2, Tabel 3 dan Tabel 4 didapatkan informasi hubungan antara jarak terminal client ke Access Point terhadap bit rate, initial time, latency dan kualitas gambar, dimana terdapat perbedaan kecepatan data (bit rate) antara smartphone 1 dan smartphone 2, tablet 1 dan tablet 2 serta notebook 1 dan notebook 2. Walaupun perbedaan ini tidak terlalu besar, tetapi perbedaan ini berpengaruh terhadap parameter lainnya, yaitu: lama waktu munculnya file video streaming di terminal client (initial time), latency dan kualitas gambar.

Dari Tabel 2, Tabel 3 dan Tabel 4 didapatkan informasi bahwa semakin jauh jarak terminal client ke Access Point maka bit rate, initial time, latency dan kualitas gambar semakin menurun, dan berlaku untuk semua terminal client.

Dari Tabel 2, Tabel 3 dan Tabel 4 didapatkan informasi bahwa dengan menurunnya bit rate membuat lama waktu munculnya file video streaming di terminal client (initial time) semakin lama sedangkan besarnya latency dapat dianggap stabil.

Dari Tabel 2, Tabel 3 dan Tabel 4 didapatkan informasi bahwa dengan waktu munculnya file video streaming di terminal client (initial time) di atas $20 \mathrm{~s}$ (20 detik) maka kualitas gambar berkurang, dan

dalam penelitian ini dikategorikan dengan predikat Cukup.

\section{KESIMPULAN}

Dari analisa yang dihasilkan dari penelitian ini maka dapat disimpulkan bahwa terdapat perbedaan kecepatan data (bit rate) antara smartphone 1 dan smartphone 2, tablet 1 dan tablet 2 serta notebook 1 dan notebook 2. Walaupun perbedaan ini tidak terlalu besar, tetapi perbedaan ini berpengaruh terhadap parameter lainnya, yaitu: lama waktu munculnya file video streaming di terminal client (initial time), latency dan kualitas gambar. Semakin jauh jarak terminal client ke Access Point maka bit rate, initial time, latency dan kualitas gambar semakin menurun, dan berlaku untuk semua terminal client. Dengan menurunnya bit rate membuat lama waktu munculnya file video streaming di terminal client (initial time) semakin lama sedangkan besarnya latency dapat dianggap stabil.

\section{DAFTER PUSTAKA}

[1] Damendra (2010). Implementasi Televisi Kampus Teknik Informatika Universitas Islam Negeri Suska Riau Dengan Menggunakan Teknologi Video Streaming Dan Audio Broadcasting Berbasis Web. Universitas Islam Negeri Sultan Syarif Kasim. Riau.

[2] George Holzmann, IAEM Stream (2008). OnDemand Streaming Server Product. Journal of Institute of Electronic Music and Acoustic (IEM). University of Music and Dramatic Arts Graz, Austria.

[3] Hidayat, Taufik (2018). Konfigurasi Video Streaming Menggunakan VLC. (Diambil dari internet:

http://taufiqth13.blogspot.co.id/2015/01/konfigu rasi-video-streaming-menggunakan.html tanggal 27 Maret 2018).

[4] Moch.Yusron (2108). Rancang Bangun Penyiaran Televisi Berbasis Web Untuk Daerah Pedesaan Di Baturetno Bantul. Sekolah Tinggi Teknologi Indonesia. Jakarta.

[5] Selma Gulen. IPTV (Internet Protocol Television). (Diambil dari internet: http://yildiz.edu.tr/ kunal/datacomdsy/IPTV\%2 Opresentation_V2.pdf tanggal 28 Maret 2018).

[6] Meeyoung Cha, MPI-SWS Saarbrücken, Germany; Pablo Rodriguez \& Xavier Amatriain, Telefonica Research Barcelona, Spain; Jon Crowcroft, University of Cambridge Cambridge, UK; Sue Moon KAIST Daejeon, Korea (2008). Watching Television Over an IP Network (Diambil dari internet: https://www.cs.princeton.edu/courses/archive/fa 1110/cos561/papers/MeasureIPTV08.pdf tanggal 29 Maret 2018).

Copyright @2016 PROtek : Jurnal Ilmiah Teknik Elektro cc (†) (-) lisensi Creative Commons Attribution 4.0 International License 